\title{
TRUMPOVA DOKTRINA I REALISTIČKA TRADICIJA
}

\author{
Petar Popović \\ Fakultet političkih znanosti \\ Sveučilište u Zagrebu
}

\begin{abstract}
SAŽETAK
Polazište ovog rada nedavni je prijepor suvremenih realista oko aktualne dvojbe je li vanjskopolitička doktrina američkog predsjednika Donalda Trumpa realistička. Autor ukazuje da je navedena polemika posljedicom zastarjelog, tautološkog, ali još uvijek i neprevladanog dualističkog diskursa u teorijama međunarodnih odnosa, koji dijeli teoriju i vanjskopolitičku praksu na dva dominantna pravca: realizam i liberalizam. Na temelju dosadašnje teorijske kritike novog realizma, ili neorealizma, članak potvrđuje da ovaj suvremeni realistički pravac epistemološki ne pripada tradiciji realizma na koju se poziva, nego se svojim predodžbama o moći, državi i međunarodnom sustavu utemeljuje u političkom idealizmu: pravcu mišljenja koji se redovno pripisuje liberalima i kojemu je tradicionalni, ili „klasični“ realizam bitno suprotstavljen. Analizirajući glavne podudarnosti između pretpostavki neorealizma i načela Trumpove doktrine, ovaj rad navodi na zaključak da Trump nije realist nego protuliberalni idealist. Pojam „protuliberalni idealizam“ prikladniji je za razmatranje aktualne američke vanjske politike u kontekstu njene hegemonijske pozicije u liberalnom međunarodnom poretku.
\end{abstract}

KLJUČNE RIJEČI: Trump, realizam, neorealizam, liberalizam, idealizam

\section{UvOD}

Tijekom 2016, dok se Donald Trump natjecao za republikansku nominaciju na nadolazećim američkim predsjedničkim izborima, politolog Daniel Drezner objavio je članak u Washington Postu, u kojem otvoreno poziva realiste $u$ američkoj akademskoj zajednici da prigrle Trumpa kao svog kandidata. Trumpov „hladni realizam“, tvrdio je, omogućiti će realistima da nakon skoro trideset godina izađu iz sjene i na tržištu se ideja nametnu 
kao relevantni savjetodavni čimbenik (Drezner 2016). Trump je pobijedio na izborima i u svom inauguracijskom govoru u siječnju 2017. iznio bitno određenje svoje vanjskopolitičke doktrine America First: „Pravo je svake nacije da svoje interese stavi na prvo mjesto. Mi ne želimo nikome nametati naš način života, nego naprotiv, želimo zasjati kao svijetao primjer drugima da nas slijede“ (The Inaugural Address 2017). Bila je to ohrabrujuća poruka i zaista se činilo da će realizam, koji je dominirao kako akademskom zajednicom tako i koridorima vanjskopolitičkog odlučivanja dobrim dijelom dvadesetog stoljeća, dobiti drugu priliku. Američki su realisti prigrlili Trumpa ali veoma oprezno, jer je od početka njegova agresivna retorika i nepredvidivost u donošenju odluka izazivala sumnje. Povelo se nekoliko nepovezanih rasprava, u kojima se baratalo uobičajenim realističkim načelima i pojmovima u kontekstu prirode Trumpovih ideoloških stavova, predizbornih obećanja i realnih mogućnosti njihova ispunjenja. ' Kao i većina kvaziteorijskih rasprava o recentnim vanjskopolitičkim pitanjima, ova je bila još jedna akademska bura u čaši vode. Međutim, pod površinom ove naoko beznačajne polemike uočavaju se dublje dimenzije krize realističke teorije.

Svrha ovog članka je da kroz analizu kritike realizma razriješi dvojbu i teorijski odredi Trumpovu doktrinu. Valja na početku istaći da realizam nije jedinstvena teorijska tradicija, kao što je još sredinom osamdesetih godina dvadesetog stoljeća ukazao Richard Ashley (Ashley 1984). U stvari, striktno govoreći, Kenneth Waltz je u pravu kada kaže da je s njim, odnosno s njegovom studijom Teorija međunarodne politike iz 1979, utemeljena realistička teorija: „novi“ realizam ili neorealizam (Waltz 1990). Sve prije neorealizma je „klasična“ realistička misao, koja seže do Tukidida u antici, te se razvija preko Machiavellija i Hobbesa, Clausewitza i Webera, do modernih realista sredine dvadesetog stoljeća Edwarda H. Carra, Hansa J. Morgenthaua, Reinholda Niebuhra, Henrya A. Kissingera i drugih. Waltzov je iskorak radikalan. Izuzev preuzimanja nekih temeljnih realističkih pojmova kao što su moć, nacionalni interes ili ravnoteža snaga kojima održava intelektualni kontinuitet s tradicijom, on svoju znanstvenu teoriju, rasterećenu od političke misli, utemeljuje u strukturalizmu. U kratkim crtama, neorealizam polazi od pretpostavke da anarhična struktura međunarodnog sustava predstavlja skup organizirajućih principa koji uvjetuju ponašanje država. ${ }^{2}$ Posebne karakteristike određene

1 U prvom poglavlju ovog rada iznijeti će se samo neki od tih komentara u raspravi. Diskusija se uglavnom vodila putem časopisa. Jednu od značajnijih objavio je The International Security Studies Forum, a vodila se između dvojice neorealista Roberta Jervisa i Randalla Schwellera, a koja je naknadno objavljenja kao knjiga (Jervis i Gavin 2018).

2 Struktura predstavlja treću predodžbu ili razinu analize. Prve dvije, koje Waltz odbacuje, su „čovjek” i „država”. 
države kao „jedinice“ (unit) su beznačajne (primjerice, povijesno iskustvo ili državni oblik vlasti). Pitanje rata i mira isključivo je pitanje djelovanja strukture, stoga u središtu je pozornosti neorealističke analize razmatranje sistematske „raspodjele moći“ među jedinicama i njihovih „materijalnih sposobnosti“.

Kriza neorealizma počinje devedesetih godina dvadesetog stoljeća, ali ne samo zato što neorealizam nije mogao predvidjeti i objasniti raspad Sovjetskog Saveza; ne ni zato što će u narednom desetljeću dominirati suparnička teorija liberalizma, opijena endističkim idejama o „kraju povijesti“, koja završava „demokratskim mirom“ i „trgovinskom međuovisnošću“; ne ni zato što se u akademskoj zajednici pojavila jaka opozicija poststrukturalnih i konstruktivističkih teorija. Ponajprije, kriza je to realističkog identiteta koja proizlazi iz radikalnog raskida s „klasičnom“ tradicijom, a čija rehabilitacija u posljednja dva desetljeća ne predstavlja samo renesansu u povijesti političkih ideja, nego se nameće kao relevantni misaoni pravac u suvremenoj političkoj misli o međunarodnim odnosima. ${ }^{3}$

Fenomen Trumpa samo je posljednji u nizu potresa koji podriva autoritet neorealizma. Ovaj članak će pokazati da Trump nije realist, nego „protuliberalni idealist“ - pojam koji se u ovom radu izvodi kao sinteza kategorije koja je u „klasičnom“ realizmu poznata kao „utopizam“ ili „revolucionarna" tradicija (Carr 2001; Kissinger 1976; Wight 1991), te recentnih određenja Trumpove političke doktrine kao „protuliberalne“ (npr. Posen 2018; Stokes 2018). Kako bi se ova pretpostavka dokazala, potrebno je izaći izvan ustaljenih teorijskih okvira antitetičke podjele na realizam i liberalizam i vratiti se prvobitnoj epistemološkoj podjeli „klasičnih“ realista na realizam i idealizam. Po tom kriteriju, neorealizam nije realistička nego idealistička teorija jer je utemeljen u racionalizmu. Središnji će dio rada izložiti bitne podudarnosti između osnovnih načela Trumpove doktrine i teorijskih pretpostavki neorealizma, kako bi se pokazalo da America First u konačnici jest politički idealizam, sadržajno određen kao nacionalistička ideologija. Riječ je o jednoj revolucionarnoj protuliberalnoj doktrini koja se svojim unilateralnim djelovanjem i nacionalističkom retorikom javlja kao izazov današnjem liberalnom međunarodnom poretku, a samim time i liberalnoj hegemoniji SAD.

3 Rehabilitacija „klasičnog“ realizma u prvom je redu rehabilitacija političke teorije međunarodnih odnosa, počevši s Tragičnom vizijom politike R. N. Lebowa (Lebow 2003), koji potvrđuje trajnu relevantnost načela realizma od Tukidida do Morgenthaua. O recentnosti „klasičnog“ realizma pisali su među ostalima: Craig (2003); Molloy (2006); Williams (2005, 2007); Tjalve (2008); Bell (2009); Barkin (2010); Scheuerman (2011); Navari (2017), itd. 
POLITIČKE PERSPEKTIVE

ČLANCI I STUDIJE

\section{DVOJBENI REALIZAM „PRINCIPIJELNOG REALIZMA“}

Kategorijalna podjela na realizam i liberalizam okvirno se javlja pedesetih godina dvadesetog stoljeća u SAD (Guilhot 2011). Iako se intelektualna ishodišta ove binarne konstrukcije nalaze u bogatoj tradiciji europske političke misli, ona je odraz posebno američkog političkog iskustva. Danas je ta podjela tautološka, te se epiteti „realist“ ili „liberal“ uglavnom pridaju američkim državnicima. Robert Kagan kaže kako je za razliku od europskih imperijalnih sila SAD od svog nastanka bio liberalan; svojevrsni „savjesni behemot" kojemu je liberalno uređenje odredilo povijesnu ulogu u svijetu i uvjetovalo ponašanje kao kombinaciju realističke obrane i idealističkog promicanja liberalnih vrijednosti (Kagan 2002). Kissinger ove dvije vanjskopolitičke perspektive jedinstvenog interesa američkog liberalnog uređenja simbolički utjelovljuje u dvojici predsjednika: republikancu Theodoru Rooseveltu (1901-1909) i demokratu Woodrowu Wilsonu (1913-1921). Obojica dijele nepokolebljivu vjeru u univerzalno poslanje liberalnog SAD, ali se razlikuju u vanjskopolitičkom pristupu. Roosevelt se oslanja na realističke principe politike moći (Realpolitik) i na jasno definiranom nacionalnom interesu; Wilson se oslanja na ideal „kolektivne snage“ demokratskih nacija, utemeljen na zajedničkoj moralnoj svijesti i vrlinama liberalnog društva (Kissinger 200o, 2. poglavlje; usporedi s Kissinger 2015, poglavlje 7).

Početkom dvadesetog stoljeća, te su dvije vanjskopolitičke pozicije poznate kao „izolacionizam“ i ,intervencionizam“. Na kraju stoljeća, s učvršćivanjem američke globalne hegemonije i intervencionizmom kao normom, perspektive su se izmijenile, ali neka supstancijalna načela realizma i liberalizma ostaju netaknuta. ${ }^{4} \mathrm{Za}$ liberale, pitanje hegemonije u stvari je pitanje legitimiteta međunarodnog poretka, kojega SAD kao dominantna sila gradi na svoju sliku i priliku (Latham 1997; Ikenberry et al. 2008; Ikenberry 2012). ${ }^{5}$ Legitimitet proizlazi iz iskrene predanosti SAD da promovira vlastiti interes kao kolektivni interes (na primjer: slobodno

4 Iako je američki izolacionizam kao politika s Drugim svjetskim ratom definitivno prevladan, svijest o državi kao nacionalno koherentnoj cjelini, suverenoj na ograničenom tlu, ostao je i dalje prisutni politički sentiment. Postepeno stvaranje američke hegemonije redefiniralo je nacionalni interes isključivo po sadržaju, ali ne i svrsi koja se poziva na „nacionalni interes" kao odraz jedinstvenih nacionalnih težnji. Taj sentiment izolacionizma, koji stavlja naglasak na nacionalni interes i vojnu moć države, snažno je naglašen u Trumpovoj doktrini. To je navelo mnoge Trumpove kritičare da ga označe izolacionistom, iako on niti je izolacionist niti je takva politika više moguća (Carpenter 2018). Ova primjedba samo pokušava ukazati koliko je izolacionizam idejno srodan realističkoj misli.

5 Koncepcija liberalne hegemonije razvija se na pretpostavkama „teorije hegemonijske stabilnosti”, koju je na polju ekonomske povijesti razvio početkom sedamdesetih godina dvadesetog stoljeća Charles Kindelberger (Kindelberger 2013). 
tržište, demokraciju, ljudska prava). On nastupa benevolentno u vidu ponude ekonomskih i sigurnosnih „usluga“ partnerima, čime dokida regionalne ekonomske sukobe i sigurnosne prijetnje, stvarajući pretpostavke za kolektivnu suradnju i institucionalizaciju međunarodnih pravila i normi. Nasuprot liberalnoj perspektivi, realizam gradi predodžbu o hegemoniji prinude (Gilpin 1981; Mearsheimer 2001). Legitimnost poretka počiva na pragmatičnom promicanju liberalnih vrijednosti, dok je u stvarnom nacionalnom interesu stvaranje slobodnotrgovinskih zona u kojima američka ekonomija ima znatnu prednost, prinudno naplaćivanje „usluga“ partnerima, te podržavanje, odnosno rušenje diktatorskih režima po kriteriju lojalnosti. Dakle, američka vanjska politika u trajnoj je tenziji predodžbe „prvog među jednakima“ u liberalnom međunarodnom poretku, s jedne, i nacionalne ekskluzivnosti, s druge strane. Tenzija je ta koja će obilježiti američku vanjskopolitičku povijest od ranog Hladnog rata do pojave Trumpa.

U praksi, doktrina America First počiva na programu vanjskopolitičke strategije pod nazivom principled realism, odnosno „principijelni realizam“. Budući da je Trumpova administracija desna republikanska, pozivanje na tradiciju koja zastupa nacionalni interes i Realpolitik ne čini se spornim. Ipak, izraz „principijelni realizam“, kojega je Trump sveukupno četiri puta upotrijebio tijekom posljednjih dvije godine svog mandata, pokazuje se prijepornim kako zbog svojih koncepcijskih nedorečenosti tako i zbog navodnog odmaka od tradicionalnih načela realizma. Nedostatak jasnog određenja naveo je jednog od Trumpovih kritičara da primijeti kako nije jasno „predstavlja li strategija ideju po kojoj se trebaju slijediti principi realizma, ili treba realistički slijediti principe“? ${ }^{6} \mathrm{U}$ govoru pred Općom skupštinom UN-a, u rujnu 2018, Trump je dao tek negativno određenje strategije, kao one koja odbacuje dosadašnje „diskreditirane ideologije“, te nadodaje kako: „(principijelni realizam) nastupa s iskrenim priznavanjem činjeničnog stanja“ (Remarks by President Trump..., 2018). „Iskrenost“ kao principijelnost i „priznavanje činjenica“ kao realistički pristup zbilji plitka je konstatacija koja ništa bitno ne otkriva. Niti dokument National Security Strategy (Nacionalna sigurnosna strategija, NSS), objavljen godinu dana

6 Paul Stares, viši suradnik u američkom Vijeću za međunarodne odnose (Council for Foreign Relations) tvrdi da je sam naziv strategije proturječan, jer realizam tradicionalno gleda na međunarodnu politiku kao područje slobodno od bilo kakvih principa. To se proturječje odražava i na samu vanjskopolitičku praksu. Primjerice, Trumpovo povlačenje iz dogovora oko iranskog nuklearnog programa je principijelno, ali ne i realističko u smislu stvarnih američkih interesa. S druge strane, pristupanje pregovorima oko obuzdavanja sjevernokorejskog nuklearnog programa je realističko bez principa, jer je tim činom dat legitimitet odmetnutom totalitarnom režimu Kim Jong Una (vidi intervju sa Stareom u: Heldeyang 2018). 
ranije i u kojem su sadržajno izložena programska načela doktrine America First, ne otkriva mnogo. ${ }^{7}$

Ipak, jedan paragraf u NSS-u privlači pozornost; onaj u kojem se obrazlaže motiv upotrebe pojma „realizma“: „(Strategija) je realistička zato što priznaje središnju ulogu moći u međunarodnoj politici, potvrđuje da su snažne i suverene države najbolja nada za miroljubivi svijet, te jasno definira nacionalni interes" (Trump 2017, 55).

Ovaj kratki navod indikativan je i dostatan za razumijevanje cjelokupne doktrinarne podloge Trumpove vanjske politike. Tri spomenuta pojma: moć, suverena država i nacionalni interes, razotkrivaju specifično intelektualno uporište u neorealizmu. Stanovište NSS-a izravno se nadovezuje na tri ključne neorealističke pretpostavke: moć shvaćena u materijalnom smislu (u prvom redu vojna moć); suverena država kao temeljna jedinica međunarodnog sustava; te nacionalni interes shvaćen funkcionalno (samopomoć, selfhelp), u vidu povećanja materijalne moći radi opstanka u anarhičnom sustavu (Jović 2013; posebno Novičić 2013; također, Vukadinović 2005). Dok zdvajaju nad značenjem „principijelnog realizma“, Trumpovi kritičari sasvim pogrešno zaključuju da Trump ovim izrazom prikriva svoj vanjskopolitički oportunizam i sirovost svoje „transakcijske“ vanjske politike. ${ }^{8}$ Oni tvrde da je zvučni naziv „principijelni realizam“ zloporaba tradicije realizma kako bi jedna „od danas do sutra“ vanjska politika, lišena svakog moralnog ograničenja i vizije, dobila na „intelektualnoj težini“ (Kirkery 2018; Grgić 2018). Međutim, ti kritičari previđaju da tako konstruirana predodžba o zbilji svijeta - nesigurnog svijeta, u kojemu su sva sredstva u borbi za goli opstanak dopuštena - jest temeljna neorealistička paradigma. Zoltan Feher uočio je niz podudarnosti između glavnih predizbornih obećanja America First platforme i koncepcija suvremenih neorealista, kao što su John Mearsheimer, Stephen Walt, Robert Art, Barry Posen i Christopher Layne. Prvo, Trump je izričito zahtijevao pravičniju raspodjelu financijske odgovornosti i ulaganja u NATO savezu, što je u skladu s hegemonijom prinude koju zastupaju svi neorealisti. Drugo, Trump je najavljivao vojno povlačenje iz Europe i Azije, što se podudara s Layneovom koncepcijom „offshore balansiranja“ (offshore balancing). 9

7 Strategija vrvi uobičajenim sigurnosnim diskursom, obrazlažući četiri stupa nacionalnog interesa: 1) zaštita domovine; 2) promicanje američkog prosperiteta; 3) snagom održavan mir; te 4) širenje američkog utjecaja.

8 Transakcijsku vanjsku politiku karakterizira menadžerska tehnika djelovanja i nedostatak političke vizije. Načelo kojim se vodi je izvlačenje apsolutne dobiti nauštrb kako saveznika tako i neprijatelja (Nye 2014). Doktrina America First u praksi se svodi na cost-benefit izračun: tko je voljan platiti, taj će dobiti zaštitu i pomoć SAD (Stokes 2018).

9 Koncept "offshore balansiranje" prvi je razvio Layne (1997) kao stratešku alternativu liberalnoj hegemoniji SAD. Ovaj koncept zagovara nemiješanje SAD-a u određene regionalne sukobe, nego „udaljeno“ podržavanje klijenata (npr. Izrael, Saudijska Arabija, Egipat itd.) u 
Treće, Trump je zastupao stajalište da daljnje proširenje NATO-a na istok Europe treba obustaviti kako bi se normalizirali odnosi s Rusijom, što je u skladu s Mearsheimerovim ranijim gledištima o američkoj pretjeranoj rastegnutosti (overstretch) na više bojišta. ${ }^{10}$ Četvrto, najavio je nepopustljivi rat protiv islamskog fundamentalizma i terorizma, sukladno Artovu konceptu „selektivnog angažiranja“ (selective engagement). ${ }^{1}$ Feher stoga zaključuje da Trumpova vanjskopolitička doktrina nije „niti nova, niti bizarna, niti radikalna“; ona je jednostavno - neorealistička (Feher 2017).

Većina je neorealista u prvi mah prepoznala realistički potencijal doktrine America First. Mearsheimer je pisao kako nova administracija ima povijesnu priliku odbacivanja „bankrotirane strategije liberalne hegemonije“, te predlaže službeno usvajanje strategije „offshore balansiranja“ (Mearsheimer 2017). Slična su i Waltova gledišta (Walt 2017). Od svih neorealista koji su u početku poduprli doktrinu America First, do danas će dosljedan u podršci ostati jedino Randall Schweller. U članku Foreign Affairs-a, pod naslovom „Tri pohvale Trumpovoj vanjskoj politici“, Schweller tvrdi kako je Trump u dvije godine mandata uspješno ostvario većinu zacrtanih vanjskopolitičkih ciljeva: na trgovinskom planu, njegov ekonomski nacionalizam uzdrmao je legitimitet multilateralnih slobodnotrgovinskih ugovora koji su išli na štetu SAD, te je objavio trgovinski rat Kini; na sigurnosnom planu, vojno je slomio Islamsku državu; i na političkom planu, obuzdao je takozvani free-riding, odnosno da SAD snosi glavni teret troškova u euroatlantskom savezništvu. Međutim, ono po čemu je Schwellerov članak zanimljiv nije njegova empirijska analiza na temelju koje pozitivno ocjenjuje Trumpovu vanjsku politiku, nego kriterij njegove prosudbe. Dvije stvari čine neorealistički kriterij ekskluzivnim: prvo, posjedovanje kognitivne sposobnosti razumijevanja same zbilje; te drugo, mudro oblikovanje odluka u skladu sa strukturnim ograničenjima koje nameće međunarodni sustav. Po Schwelleru, Trump je realist par excellence jer je on prvi shvatio da SAD više nije jedina globalna supersila posthladnoratovskog svijeta: „Trump nije stvorio ovakvu zbilju, on ju je jednostavno prepoznao“ (Schweller 2018b, 142). Američki „unipolarni moment“ definitivno je završio globalnom recesijom 2008, ustupivši mjesto multipolarnosti kao novoj zbilji koju karakterizira visoka kompetitivnost država posvećenih

uravnoteživanju snaga s neprijateljem. Takvim pristupom, osim što neizravno utječe na sukob, SAD će rasti međunarodni ugled kao posredniku.

1o Posebno obratiti pažnju na Mearsheimerov članak o ukrajinskoj krizi i osudi američkog imperijalnog hubrisa, koji je pridonio rasplamsavanju sukoba u Ukrajini (Mearsheimer 2014).

11 Strategija „selektivnog angažiranja“ odnosi se na strogo definirane ciljeve vanjske politike, i primjenu sile isključivo protiv označenih (,selektiranih“) prijetnji koje predstavljaju stupanj najviše ugroze (Art 1998/99). 
vlastitim interesima, sigurnosti i ekonomskom blagostanju. Čak i ako se na određenim područjima takva vanjska politika pokaže neuspješnom, ona je hvale vrijedna samom činjenicom što si postavlja zadatke i ciljeve u skladu sa zakonima zbilje, a ne po idealističkim uvjerenjima ideološki zaslijepljenih liberala.

Schweller je usamljeni glas. Nitko nije toliko gorljivo osporavao Trumpov navodni realizam koliko sami realisti. Robert Jervis je ustvrdio kako će Trumpova doktrina vrlo vjerojatno ostati na razini predizborne retorike. ${ }^{12}$ Primijenivši Waltzove „tri razine (ili predodžbe) analize“ i birokraciju kao intervenirajuću varijablu, autor je ukazao na niz izravnih institucionalnih i međunarodnih ograničenja, koja će jednostavno onemogućiti Trumpovo najavljeno predizborno obećanje o radikalnom raskidu s dotadašnjim vanjskopolitičkim smjernicama (Jervis 2018, 4-5). Ukoliko Trump zaista ostvari svoja obećanja, tim je više realizam njegove doktrine upitan. Naime, ako struktura uvjetuje ponašanje država, a međuovisni sustav liberalnog međunarodnog poretka svakako predstavlja zbiljsko stanje stvari; onda, koliko god da je opravdan Trumpov skepticizam oko određenih politika (npr. neravnomjerni teret troškova u NATO-u, štetnost pojedinih slobodnotrgovinskih ugovora, odnos prema Rusiji itd.), radikalna promjena vanjske politike ne bi bila u skladu s imperativima sustava, odnosno ne bi bila realistička. Međutim, Jervis sumnja u takav ishod, jer povijest je pokazala da američki predsjednici, neovisno o suprotstavljenim političkim platformama, uvijek bivaju strukturno ograničeni, stoga valja prije očekivati kontinuitet na koji eventualna promjena vanjskopolitičke metode i taktike neće mnogo utjecati. Pritom, Jervis tvrdi da Trumpova doktrina kao takva „teško da je uskladiva s realizmom; iako se ne može reći koja to alternativna teorija, ako takva uopće postoji, može opravdati principijelni realizam“? (Ibid. 5)

Peter Feaver i Hal Brands također su ustvrdili da doktrina America First nije realistička, budući da se ne temelji na tradicionalnim načelima sigurnosne strategije i političkog pragmatizma, nego u dosad neviđenom izolacionističkom povlačenju i tribalizmu. ${ }^{13} \mathrm{U}$ stvari, meta njihove oštre kritike u članku „Spašavanje realizma od takozvanih realista“ nije Trump, nego neorealisti koji su ga u prvi mah prigrlili: Mearsheimer, Walt, Lyne itd. Ti su, kako ih autori nazivaju, ,akademski realisti“ na groteskni način izvitoperili jednu veliku teorijsku tradiciju, koja njihovom „zaslugom“

12 Za reakciju i odgovor na Jervisov esej, vidi: Schweller (2018a: 22-39).

13 Sličnog je stava i konzervativni publicist Daniel Larison. On tvrdi da Trumpova fiksacija na povećanje vojne moći i prijezir koji pokazuje prema diplomaciji potvrđuje da s tradicionalnim diplomatskim pragmatizmom kojim se realizam dići on nema veze. Čak i po pitanju „prepoznavanja zbilje“, Trump uopće ne posjeduje nikakvu analitičku sposobnost svojstvenu realistima, već djeluje po iracionalnim i refleksivnim impulsima (Larison 2018). 
postaje sinonimom za prizemni oblik nacionalističkog radikalizma. Takav „realizam“ je u bitnoj suprotnosti sa uhodanim obrascima ponašanja u skladu s realističkim shvaćanjem američke hegemonije. Naime, America First doktrina smjera uništenju međunarodnih institucionalnih aranžmana koji su se izgrađivali desetljećima i uspješno jamčili stabilnost i prosperitet SAD i Zapada. Izdaja je to onog izvornog realističkog pragmatizma u tradiciji Georga Kennana i Henrya Kissingera, a koji je prepoznao „da će moć SAD biti najdjelotvornija ako se upregne s neodoljivim koncepcijama američke moralne svrhe i primijeni kroz trajnu suradnju s nacijama koje sa SAD dijele neke zajedničke temeljne vrijednosti“ (Brands i Feaver 2017).

Optimizam u pogledu realističkog potencijala doktrine America First od samog je početka bio akademski mjehur na tržištu ideja, koji se rasprsnuo prvim potezima Trumpove administracije. ${ }^{14}$ Danas je većina neorealista na čelu s Mearsheimerom i Waltom u najmanju ruku razočarana (Walt 2018; Posen 2018). Međutim, to nipošto ne znači da su u pravu oni kritičari koji su tvrdili da „principijelni realizam“ nije ništa drugo do obični simbolički slogan bez teorijskog uporišta. „Principijelni realizam“ zaista ima utemeljenje u neorealizmu i to je, paradoksalno, glavni izvor sporenja. Naime, cjelokupni se prijepor svodi na dvojbu je li Trumpovo aktivno podrivanje liberalnog međunarodnog poretka, pa samim time i američke liberalne hegemonije, realističko u smislu prepoznavanja zbilje i djelovanja u skladu s strukturnim ograničenjima sustava? Ovaj prijepor je više politički nego akademski, čemu u prilog govori i činjenica da je polemika oko Trumpove doktrine izrazito jakog ideološkog naboja. ${ }^{15}$ Međutim, kako bi se razjasnila ova dvojba, potrebno je izdići se izvan dualističkog okvira realističko-liberalne dihotomije.

14 Primjerice, Trump ne samo da je odobrio povećanje broja vojnika u Afganistanu, nego je i odustao od time-line based strategy, kojom se trebao utvrditi konkretni rok povlačenja američkih snaga iz te zemlje; umjesto da je uravnotežio snage s Rusima na Bliskom istoku, bombardirao je Siriju; definitivno je zanemario strategiju offshore balansiranja kada se svrstao kao saveznik Izraela po pitanju „dvodržavnog rješenja“ s Palestincima; pojačao je sankcije Rusiji itd. (Stokes 2018; Walt 2018).

15 Jervis otvoreno iskazuje osobni animozitet prema Trumpu i njegovoj politici. Schweller ponosno ističe da je republikanac i da je Trump bio njegov izbor. Obojica koriste jedinstvenu neorealističku strukturalnu metodu u svojim analizama. U oštrom odgovoru Brandsu i Feaveru, Andrew Bachevic je razotkrio njihove veze s neokonzervativnim elitama, kao pozadinu njihovog ideološki motiviranog napada na Mearsheimera, Walta i druge. Njihovo pozivanje na realizam iz vremena Hladnog rata pokazuje njihovo nepoznavanje zbilje, odnosno da se od tog vremena struktura izmjenila dva puta: najprije u „unipolarnom momentu” američke liberalne hegemonije, te potom u suvremenoj multipolarnosti, a odraz koje je Trump (Bachevic 2017). 
POLITIČKE PERSPEKTIVE

ČLANCI I STUDIJE

\section{NEOREALIZAM KAO IDEOLOŠKI IDEALIZAM}

Uvjet identitetskog određenja realizma, kao teorije zbilje, zahtjeva konstituiranje njegove suprotnosti: liberalizma, kao jednog od ideoloških varijanti političkog idealizma. Ova podjela seže u same korijene nastanka akademske discipline međunarodnih odnosa, čija službena predaja bilježi navodnu pobjedu realista nad liberalnim idealistima u takozvanoj „prvoj velikoj raspravi“ tridesetih ili četrdesetih godina dvadesetog stoljeća. U stvari, ta je „rasprava“ popularizirani mit osmišljen po uzoru na razornu kritiku liberalnih „utopista“ u studiji Edwarda Carra Dvadesetogodišnja kriza iz 1939 (Carr 2001). ${ }^{16}$ Carr udara temelje danas konvencionalnom binarnom diskursu kada kaže: „Radikal je nužno utopist, a konzervativac realist (...) politička ljevica smišlja načela političkog djelovanja i razvija ideale koje državnici trebaju slijediti, ali joj nedostaje praktičnog iskustva koje proizlazi iz bliskog kontakta s zbiljom" (Carr 2001, 18-19). Na ovoj pretpostavci niknuti će desno-lijeva tautologija američkih doktrina vanjske politike. ${ }^{17}$ Međutim, što Carr podrazumijeva pod „konzervativizmom“ kada govori o realizmu, te zbog čega liberalnoj ljevici ekskluzivno pripisuje utopizam, odnosno idealizam? Za razumijevanje ove podjele potrebno je razlučiti tri razine realističke, odnosno idealističke misli (Griffith 1992, 1. poglavlje). Prva razina odnosi se na razlikovanje u teoriji znanja, koje se kategorijalno dijeli na realistički i idealistički pristup razumijevanju zbilje; druga razina je deskriptivna, te se odnosi na razlikovanje teorijskih perspektiva političkog realizma i političkog idealizma kao skupu stiliziranih pretpostavki i načela; te konačno, treća razina je preskriptivna, i odnosi se na razlikovanje vanjskopolitičkih programskih strategija i praktičnih pristupa kojima odgovara uobičajena podjela na realizam i liberalizam.

Na epistemološkoj razini, Robert Berki (1981) je ukazao kako realizam i idealizam predstavljaju suprotstavljena misaona svojstva. Realistička misao pretpostavlja zbilju kao trajni dijalektični odnos nužnosti (strukturnog determinizma) i slobode (slobodne volje u djelovanju, koje nadilazi struk-

16 Carrov napad na „utopiste“ odnosi se na kritiku nekoliko nepovezanih ličnosti iz političkog i akademskog svijeta: npr. američkog predsjednika Wilsona, pacifista Normana Angella, intelektualnog spiritus movensa Lige naroda Alfreda Zimmerna itd. Većina „utopista“ koje Carr kritizira u stvari su utilitaristi i ekonomski liberali devetnaestog stoljeća, a što je i slučaj u Morgenthauovoj kritici u Čovjek znanosti protiv politike moći (Morgenthau 1947). Ipak, u naknadnoj konstrukciji realističko-liberalnog dualizma, svi navedeni „utopisti“ biti će svrstani pod jedinstvenu tradiciju - koja, očito, u takvom obliku nikada nije postojala „liberalni idealizam“.

17 Primjerice, Mearsheimer na temelju ove nekritički i u pojednostavljenom obliku izložene podjele u uvodnom dijelu svoje studije Tragedija velikih sila izvodi svoju koncepciju „ofenzivnog realizma“" (Mearsheimer 2001, 1. poglavlje). 
turna ograničenja). U ovom relativnom odnosu, teorija se razvija iz „iskustva svakodnevnog praktičnog života“ (Berki 1981, 2); kako bi povratno djelovala na društvo i njegovu organizaciju. Idealizam, s druge strane, negira ovaj dijalektični odnos, tvrdeći da je zbilja ontološka: ili nužnost ili sloboda. Posljedično tomu, idealistička ,imaginacija“ apstrahira nužnost ili slobodu do razine koncepcijske dogme, koja u praktičnoj primjeni vodi ili $\mathrm{u}$ totalno potčinjavanje društva ili u revoluciju. U modernoj tehno-znanstvenoj epohi, idealizam nastoji utemeljiti svoju „imaginaciju“ u znanosti (prvenstveno u prirodnim znanostima), kako bi si priskrbila neprikosnoveni znanstveni autoritet u polaganju prava na univerzalnu ,istinu“. Realizam osporava ovu idealističku samouvjerenost, tvrdeći da znanje, budući da proizlazi iz iskustva, nužno je uvjetovano subjektivnim predodžbama (Neascu 2009, 8-11; Petersen 1999). Zagovaranje univerzalne „istine“ u ovom slučaju ne može biti ništa drugo do racionalizirani interes partikularnog društva ili grupe; dakle, ideologija (Jütersonke 2010, 151-160; Molloy 2004; Behr and Heath 2009; Rösch 2013).

Realizam u biti ne osporava liberalnu tradiciju slobode i jednakih prava, nego prvenstveno racionalističku političku znanost. U srcu racionalističkog pristupa liberalnog idealizma vlada uvjerenje da se valjana politička praksa postiže konstruiranjem univerzalne znanstvene metode, pomoću koje će se otkriti objektivni zakoni društvene zbilje. Politička primijenjenost „znanstveno“ otkrivenih koncepcija vodi u društveni inženjering, a to je ono čemu se Carr i cjelokupni intelektualni pokret „klasičnog“ realizma protive. To je pravi smisao onog „konzervativnog“ u Carrovom realizmu (Cox 2000; Molloy 2003; Babik 2013). ${ }^{18}$ Također, time se podrazumijeva da idealizam nije ekskluzivno svojstvo liberalizma i ljevice, nego je potencijalno svojstven bilo kojoj političkoj teoriji koja bi svoja načela, koncepte i pretpostavke postavila na pijedestal „znanstveno“ utvrđene univerzalne „istine“. 19 Riječ je o epistemološkom sukobu relativnog i apsolutnog; refleksivnog i racionalističkog; praktičnog iskustva i apstraktnog koncepta; antiideologije i ideologije. A upravo ova dihotomija u bitnom smislu razdvaja „klasični“ realizam od neorealizma. Potonji sebe smatra nasljednikom „klasične“ realističke tradicije, ali to samoproglašeno naslijeđe tek je na razini deskripcije, u prihvaćanju nekih općih načela i pretpostavki o moći,

18 To je i središnje značenje Morgenthauove kritike u studiji Čovjek znanosti protiv politike moći (1947), koja napada čvrstu vjeru liberalnog racionalizma da znanošću može riješiti kompleksne društvene probleme (konkretno rat) kroz primjenu metoda prirodnih znanosti, a koja je u konačnici nesposobna razumjeti i suočiti se s erupcijom iracionalnih snaga dvadesetog stoljeća: masovnoj politici, industrijaliziranom ratu, totalitarizmu, genocidu itd. (Bell 2009; Lazović 2013).

19 Iako nikada nisu bili predmetom sustavne kritike, realizam u ovu kategoriju smješta i marksizam i radikalni nacionalizam, u obliku ondašnjih fašističkih pokreta (Morgenthau 1970, poglavlje 23; te 2006, poglavlje 7). 
POLITIČKE PERSPEKTIVE

ČLANCI I STUDIJE

državi i međunarodnom sustavu. No, neorealizam u bitnom epistemološkom smislu utemeljenje nalazi u političkom idealizmu. ${ }^{20}$

Osnivač ovog teorijskog pravca Waltz tvrdi da se valjana teorija ne smije zanimati za „sve što se događa u međunarodnoj politici“, već joj je potreban „vitalni eksplanatorni konstrukt“ (Waltz 1990, 32). U duhu liberalnog racionalizma, on kaže da teorija mora biti apstrahirana od empirijske zbilje (dakle, od svakog iskustva) i oblikovana kao kognitivna predodžba specifične društvene aktivnosti (međunarodne politike) u svrhu predviđanja, te nadasve „kontroliranja“ zbilje (Waltz 2008, 1. poglavlje). Pretendirajući na neprikosnoveni znanstveni autoritet temeljem otkrivanja univerzalnih zakona međunarodne politike, neorealizam prirodu apstraktnih koncepcija o moći, državi i međunarodnom sustavu poistovjećuje s prirodom međunarodne politike. Mearsheimer tako kaže da je neorealizam teorija „materijalnih struktura koje uvjetuju ponašanje država“, iz čega proizlazi da je praksa valjana ako je u skladu s mehaničkim zakonima sustava (Mearsheimer 1994, 41). Dakle, epistemološke razlike između novog realizma i liberalizma nema, (čemu u prilog svjedoči i „unutarparadigmatska rasprava“), ${ }^{21}$ dok se razlikuju tek u deskripciji: umjesto slobode, neorealizam zagovara nužnost u vidu strukturnog determinizma.

Kako je u prethodnom dijelu istaknuto, strategija „principijelnog realizma“" polazi od načelnih pretpostavki da je borba za moć bitna karakteristika međunarodne politike, te da je za miroljubiv svijet nužno potrebna vojno i ekonomski jaka suverena država. Iako u deskriptivnom smislu to jesu načelno pretpostavke realističke tradicije, Waltz im je u procesu pojmovne racionalizacije izmijenio smisao, primjenjujući ono što Morgenthau kritizira kao racionalistički „redukcionizam“ (Morgenthau 1970, 241248). ${ }^{22}$

20 Kao što je ranije napomenuto, „liberalni idealizam“ kao jedinstvena tradicija u međunarodnim odnosima nije nikada postojao, nego se ovaj naziv načelno odnosi na racionalističku političku znanost kao skup pretpostavki, mikroekonomskih modela i empirijskih metoda preuzetih iz klasičnog liberalizma.

21 Riječ je o takozvanoj „trećoj velikoj raspravi“ neorealizma i neoliberalizma osamdesetih godina dvadesetog stoljeća, koju je Ole Waever prozvao „neo-neo sintezom“ (Waever 1996). Prihvativši sve temeljne pretpostavke neorealizma: državu kao jedinstvenog racionalnog aktera, moć, anarhični sustav, „nova” varijanta liberalizma, čiji su glavni predstavnici Robert Keohane i Joseph S. Nye, svela se na neorealističku granu koja razmatra suradnju među državama i njihovu apsolutnu dobit, umjesto nepovjerenja i posljedične relativne dobiti.

22 Ovdje navedena Morgenthauova kritika datira iz sredine šezdesetih godina dvadesetog stoljeća i odnosi se na rane američke teorije međunarodnih odnosa koje prethode neorealizmu: npr. bihejvioralne teorije, simulacija, teorija igre itd. Međutim, bitni smisao kritike savršeno je primjenjiv i na neorealizam. 
Redukcionizam pretpostavlja dedukcijsko svođenje zbilje na pojednostavljene teorijske sheme, podložne kvantitativnom mjerenju. ${ }^{23}$ Posljedično tomu, kako kaže Morgenthau, teorija gubi iz vida važne čimbenike koji uvjetuju međunarodnu politiku, kao što su moralne dvojbe, rizici u donošenju političkih odluka i intelektualna zdvajanja nad stanovitom međunarodnom problematikom (Ibid. 243). Tako će Waltz jedan od najkompleksnijih fenomena međunarodne politike - moć - svesti na elementarne materijalne snage države; konkretno, na vojnu moć. Jer, po Waltzu, znanstvena je analiza međunarodne politike valjana kada se „moć procjenjuje uspoređivanjem (materijalnih, op.a.) sposobnosti određenog broja jedinica“ (Waltz 2008, 110). Ovaj pristup bitno odudara od „klasičnog“ realističkog poimanja moći, kao epistemološkog „putokaza“ za razumijevanje moralnih i sociopolitičkih implikacija društvene iracionalnosti, psihološki uvjetovane inherentnom „težnjom k moći“ (Williams 2007, 118-127; Tjalve 2008, 97-136; Rösch 2013).

Neposredna je implikacija ove intelektualne zablude neorealizma konstruiranje društvene predodžbe koja će psihološku kategoriju političke moći razumjeti isključivo u terminima sile. Kada se na temelju takve predodžbe oblikuje interes, političko se u vanjskopolitičkom odlučivanju nužno mora povući pred vojnim. Rezultat toga je militarizacija politike, za koju Morgenthau kaže da „ne razumije paradoksalnu činjenicu da povećanje materijalne moći nužno ne znači povećanje sveukupne nacionalne moći“, te dodaje kako će konačni rezultat one politike, koja sve kapacitete podredi povećanju materijalne moći, državu suočit s činjenicom „da nema prijatelje, samo vazale i neprijatelje“ (Morgenthau 2006, 174). ${ }^{24}$ Materijalistička predodžba o moći kao sili u bitnom smislu oblikuje Trumpov pogled na svijet, eksplicitno izložen u njegovoj knjizi Great Again:

Moj pristup vanjskoj politici izgrađen je na snažnim temeljima: djeluj na temelju svoje snage. To znači da moramo zadržati status naše vojske kao

23 U slučaju neorealizma konkretno je riječ o mikroekonomskom modelu na kojemu je sazdana treća predodžba međunarodnog sustava, koji je analogan tržištu, države kompanijama, a ravnoteža snaga mehanizmu „nevidljive ruke” Adama Smitha. Dobrobit općeg mehaničkog uravnoteživanja jest opstanak aktera na međunarodnoj sceni. A da li će određena država opstati ovisi o, kako Waltz kaže: „njenom vlastitom naporu (...) Međunarodna politika predstavlja područje u kojemu je sve dozvoljeno. Ona je strukturno slična tržišnoj ekonomiji onoliko koliko je načelu samopomoći dozvoljeno da djeluje u tržišnoj ekonomiji (Waltz 2008, 103).

24 Morgenthauovo poimanje moći istovjetno je poimanju H. Arendt, koja strogo razlikuje moć i silu. Dok moć počiva na društvenom pluralitetu javno-političkog prostora, sila počiva na materijalnim sredstvima i kao takvoj društvena joj brojnost nije potrebna. Arendt kaže: „Gdje se sila, koja je zapravo fenomen pojedinca ili malobrojnih, povezuje s moći, koja je moguća samo među mnogima, nastaje nečuveno povišenje potencijala sile koje sa svoje strane, doduše, potaknuto moći organiziranog prostora, međutim, potom kao i svaki potencijal sile narasta i razvija se nauštrb moći“ (Arendt 2013, 56). 
POLITIČKE PERSPEKTIVE

ČLANCI I STUDIJE

daleko najmoćnije na svijetu. Moramo iskazati našu volju da uporabimo našu ekonomsku snagu kako bismo nagradili one zemlje koje s nama surađuju i kaznili one koje to ne čine (...) Također moramo stupiti u savezništva s našim partnerima s kojima imamo zajedničke koristi (...) Moramo potrošiti koliko je god potrebno novaca da u cijelosti financiramo svoju vojsku (Trump 2015, 30).

Poglavlje iz kojega je navod preuzet nosi naslov „Borba za mir“, što je veoma indikativno i daleko od bilo kakve ironije. Naime, Trump je zaista čvrstog uvjerenja da su politička stabilnost i red u međunarodnoj sferi mogući jedino na temelju vojne premoći države. Takvu vrstu idealizma Morgenthau je svojedobno označio kao viziju takozvane „makijavelističke utopije“, za koju je karakteristično „zanemarivanje dubokog jaza između kvalitete političke inteligencije i kvalitete političke prakse" (Morgenthau 1945, 145). ${ }^{25}$ Već u ožujku 2017, samo dva mjeseca otkako je postao predsjednik, Trump je predložio povećanje proračuna za Ministarstvo obrane na 639.00o.ooo.ooo dolara, što je oko 54.00o.ooo.ooo dolara više u odnosu na prethodne godine. Veoma je znakovito da je prenamjena novca trebala ići na štetu godišnjeg proračuna predviđenog za State Department (28\%), inozemnu pomoć, te UN-ove programe; dakle, na štetu diplomacije.

Doduše, militarizacija američke vanjske politike proces je koji traje još od administracije Georga W. Busha i njegovog pokretanja „rata protiv terorizma“ 2001, a koji se nastavio i pod predsjedništvom Baraka Obame. Međutim, militarizacija vrhunac doživljava upravo pod Trumpom, koji je dao potpuno odriješite ruke Pentagonu da po vlastitoj prosudbi donosi odluke. Kada je u proljeće 2017. Trump izjavio da prepušta svu odgovornost generalima jer im vjeruje više nego političarima (Scarborough 2017) bio je to konačni krah političkog pred vojnim. Politički interes tako postaje vojni interes, a vojnoj je sferi relativna priroda političkog strana. Vojna sfera razmišlja logikom efikasnosti provedbe konkretne strategije, koja u svojoj bezobzirnosti prema mogućoj „kolateralnoj šteti“ može uključivati i prekomjernu upotrebu sile (npr. bacanje „majke svih bombi“ na uporište Islamske države u Afganistanu).

Svođenje moći na silu zaokružuje se u imaginaciji države kao jedinstvenog djelatnog aktera u sustavu, zbog čega „principijelni realizam“ i stavlja naglasak na suverenu državu kao jamstvo mira. Hartmut Behr i Amelia Heath (2009) pokazali su da je Waltz svoju ideološku pristrasnost u konceptualizaciji pojma države razvio još u svojoj doktorskoj disertaciji

25 Utopijski karakter Machiavellijeve političke filozofije Morgenthau prepoznaje u posljednjem dijelu Vladara, gdje Machiavelli smišlja pravila političkog djelovanja kao sredstvo do cilja ujedinjenja Italije. Po Morgenthauu, „utopijsko je uvjerenje“ da moć jedne od tih gradova država, „mudrom političkom upotrebom“, može dovesti do ujedinjenja i mira (Morgenthau 1945, 145). 
sredinom pedesetih godina dvadesetog stoljeća, naknadno objavljenoj pod naslovom Čovjek, država i rat. U toj studiji Waltz iskrivljuje političku misao Rousseaua i Hobbesa kako bi oblikovao predodžbu o državi kao akteru „sposobnom jedinstveno djelovati“ $u$ anarhičnom sustavu. Međutim, pretpostavka je problematična jer izaziva dvojbu oko kriterija određenja ,jedinstvenog djelovanja“: postiže li se jedinstvena vanjska politika konsenzusom svojstvenim republikanskim uređenjima, ili ju netransparentno oblikuje koncentrirana moć u središtu autoritarne vlasti? Waltz se opredjeljuje za potonje, zagovarajući svako potiskivanje kritične opozicije kroz državno sponzoriran odgoj u „domoljublju“. Pozivajući se na Rousseaovu Političku ekonomiju, Waltz kaže:

U takvoj državi sukob je eliminiran, a jedinstvo ostvareno, jer s negativnog stajališta jednakost sprječava razvoj onih parcijalnih interesa koji mogu biti pogubni za jedinstvo države; s pozitivnog stajališta, usađivanje javnog osjećaja u glavu razvija u građaninu duh odanosti i blagostanja za sve. Volja države je općenita volja; ne postoji problem nejedinstva i sukoba. U proučavanju međunarodne politike pogodno je misliti o državama kao o djelatnim cjelinama (...) To je važno mjesto za svaku teoriju međunarodnih odnosa, a posebno za treću predodžbu (Waltz 1998, 148-49).

Nadalje, Waltz od Hobbesa doslovce preuzima racionalistički konstrukt „prirodnog stanja“ kao zbiljskog uvjeta međunarodne politike. ${ }^{26}$ Belicistička predodžba anarhije, koja odražava hobsovski bellum omnnium contra omnes, nužna je za opravdanje koncepcije države kao jedinstvene „djelatne jedinice“. Budući da iznad država ne postoji jedno suvereno središte moći, metafora anarhije pretpostavlja treću predodžbu oslobođenu bilo kakve političke ili pravne regulacije, trajno sklone nepovjerenju i sukobima kao dokazu slobodnog djelovanja država. Waltz kaže: „Jedinstvo jedne nacije hrani se ne samo izvornim faktorima, nego i antagonizmima koji se često javljaju u međunarodnim odnosima“ (Ibid. 151). ${ }^{27}$ Označivši neorealizam kao američku hladnoratovsku znanost o strategiji, Behr i Heath zaključuju: „Počevši s pojmom anarhije i gotovo dedukcijski, putem ideja o samopomoći i nacionalnog interesa, Waltz izlaže ne samo pojmove nego i zahtjev (kurziv autorov) za nacionalnu i međunarodnu politiku moći, koja podra-

26 Waltz očito zanemaruje da je Hobbes svjestan međunarodne dimenzije i da mu je za međudržavnu regulaciju odnosa ključna unutardržavna legitimnost suverena kao funkcija ograničavanja njegovog djelovanja prema van (Behr and Heath 2009, 342-343).

27 Po Waltzu, anarhija ima jedinstvenu logiku, a to je „sigurnosna dilema“. Takva predodžba pretpostavlja državu ne samo kao zatvorenu cjelinu u materijalnom smislu, nego i s onim što Alexander Wendt (2009) naziva „privatnim znanjem“ o sebi i svijetu, a koji nije dijeljen s drugim državama u sustavu. Drugim riječima, oslikava se jedan primitivan sustav odnosa slabe komunikacije i nikakvog međusobnog razumijevanja, što izaziva trajno nepovjerenje i veliku mogućnost učestalih sukoba. Logiku anarhije Waltz je izveo iz Rousseaove parabole o lovu na jelena u Raspravi o porijeklu nejednakosti (Waltz 1998, 141-142). 
POLITIČKE PERSPEKTIVE

ČLANCI I STUDIJE

zumijeva povećanje moći/sigurnosti u vanjskoj i političku homogenizaciju u unutrašnjoj politici“ (Behr and Heath 2009, 339).

Elementi autoritarnosti vidljivi su iz Trumpovog menadžerskog stila vladanja državom kao kompanijom; riječ je o administraciji koja je podijelila najviše otkaza u povijesti i koja koristi sva sredstava kako bi potčinila ili nadigrala zakonodavnu vlast (npr. proglašenje izvanrednog stanja u veljači 2019. kao izgovor za ispunjenje predizbornog obećanja izgradnje zida s Meksikom). Koncept međunarodnog sustava kao anarhije svoj vjerni odraz nalazi u Trumpovoj predodžbi svijeta kao ,igri nultog zbroja“ i posljedično tomu u transakcijskoj vanjskoj politici. Savjetnik za nacionalnu sigurnost H. R. McMaster možda je na najbolji način dočarao logiku anarhije u Trumpovoj predodžbi kada je rekao da „svijet nije globalna zajednica“. Naprotiv, svijet je područje borbe za moć državnih, nedržavnih i ekonomskih aktera, i takvu „elementarnu prirodu“ međunarodne politike Trumpova administracija „ne treba negirati, nego prigrliti“ (Gvosdev 2017).

Protuliberalni idealizam Trumpove doktrine neorealizam može jedino osporavati pozivanjem na znanstveni i objektivni karakter teorije, toliko tipičan za ideologije. Argument bi glasio da neorealizam nije ideologija iz razloga što od tri predodžbe ili razine analize samo prve dvije: čovjek i država (a koje ova teorija odbacuje), mogu biti nositelji stanovitih doktrina i ideja. Treća razina, odnosno međunarodni sustav, ima vlastitu logiku (logiku anarhije), na koju ne može utjecati nikakva ideologija. S tim u skladu, Schweller upućuje „tri pohvale“ Trumpovoj vanjskoj politici. Trumpovo djelovanje na međunarodnoj sceni nije uvjetovano njegovim nacionalističkim pogledom na svijet, već svoje uspjehe duguje sposobnosti inženjera koji prepoznaje konkretni problem te ga tehnički rješava. Primjer koji kod Schwellera to najbolje ilustrira Trumpova je prijetnja da će razvrgnuti NATO. Činjenica jest da se ova vojna organizacija u posljednjih tridesetak godina preobrazila iz međudržavnog saveza kolektivne sigurnosti u interesnu organizaciju liberalnih elita. ${ }^{28}$ Ali, upravo je zbog toga Trumpov zahtjev za preustrojem ili razvrgavanjem NATO-a bitno političko pitanje, koje zahtjeva iznimnu političku inteligenciju i diplomatski pragmatizam umjesto puke prinude ili prijetnje. Međutim, to ne sprječava Schwellera da zaključi: „U konačnici, nije Trump glavni krivac za pohabane veze u NATO-u, nego međunarodna struktura“, jer, jednostavno, s krajem Hladnog rata „Europi više

28 Dokaz tome je da je prethodnih godina Islamska država preuzela odgovornost za terorističke napade u čak pet država članica NATO-a: Belgiju, Tursku, Englesku, Francusku i Njemačku, i da se niti jedna od tih država nije pozvala na članak 5. NATO-ove Povelje, koja jamči kolektivnu akciju u slučaju napada na jednu od članica. Ali kada su konkretni ideološko-ekonomski interesi označili libijskog predsjednika Moamera Gaddafija kao prijetnju, NATO se nije libio uplesti u libijski građanski rat i vojnom intervencijom srušiti Gaddafija. 
nije trebala tolika zaštita supersile, pa stoga niti Washington nije mogao imati utjecaj kao nekad“" (Schweller 2018b, 141).

Ovakvo je objašnjenje u najmanju ruku konformističko prema vladajućoj doktrini, gdje „znanost“ oslobađa analizu od bilo kakve kritičke prosudbe. Međutim, kako je istaknuo Michael Williams, racionalističke teorije međunarodnih odnosa (s neorealizmom kao vrhunskim primjerom) u konačnici će morati same sebi priznati da su i one povijesni društveni konstrukti. Naime, prvobitni motiv njihova konstituiranja jest snalaženje u kompleksnom i nestabilnom svijetu, koje se postiže primjenom racionalne i odgovorne političke analize i prakse. U središtu njihovog zanimanja „nije 'činjenica' na kojoj će podići vrijednosno neutralnu znanost o međunarodnim odnosima, nego predanost razumskom djelovanju kao vrijednosti po sebi“ (Williams 2007, 146). Stoga, ironija je da neorealizam, bježeći od ideologije, u stvari trči k njoj. Jer, ako je po neorealistima država strukturno uvjetovana anarhičnim sustavom, njihovo je vrijednosno opredijeljenje da zagovaraju djelovanje po kriteriju posve agresivne militarističke doktrine jednog autoritarnog režima.

Liberali su u tom kontekstu označeni kao neprijatelji istine i neposredna politička opasnost, budući da ne prepoznaju zbilju transpovijesnih zakona međunarodnog sustava. Iz perspektive Mannheimovog partikularnog pojma ideologije, daje se zaključiti da je neorealizam poslužio političkim elitama kako bi tijekom Hladnog rata znanstveno potvrdile racionalnost svojih političkih odluka i osporile „pogrešno mišljenje“ i „lažnu svijest" svojih političkih suparnika. Konačni je rezultat svođenje realizma na konzervativnu desnicu i liberalizma na progresivnu ljevicu. Neorealizam, koji prisvaja monopol na univerzalnu „istinu“, posljedično postaje lokalan. ${ }^{29}$ Desno-lijeva tautologija će, s promjenom društvenih uvjeta i okolnosti u posthladnoratovskom dobu, teoriju suočiti sa stanovitim anomalijama u analizama. Tako je republikansku administraciju G. W. Busha već spomenuti Peter Feaver označio kao realističku, iako je Bush bio vjerojatno jedan od najžešćih liberalnih križara u širenju demokracije poslije Wilsona (Walt 2009). Predsjednik Obama, demokrat, je apriori bio

29 Iako se neorealizam podučava na sveučilištima diljem svijeta kao „opća teorija međunarodne politike”, te se u velikom broju primjenjuje u doktorskim disertacijama, kao i znanstvenim i stručnim studijama ili analizama, ipak je uočljivo kako se kategorija „realist“ ili „liberal” isključivo pridaje američkim predsjednicima (gotovo uvijek ovisno o političkom spektru). Na druge države s različitim povijesnim iskustvima kategorije „realista” i „liberala” su neprimjenjive. Uzmimo primjer Hrvatske, čije je povijesno iskustvo posljednjih godina oblikovalo dvije suprotstavljene vanjskopolitičke pozicije: jednu koja zagovara jačanje odnosa s državama u regiji (politika bivšeg predsjednika Josipovića); i drugu, koja zagovara veći angažman u Srednjoj Europi i Višegradskoj skupini (politika predsjednice Grabar-Kitarović). Po navedenim kriterijima, koja je od tih pozicija realistička a koja liberalna sasvim je bespredmetno razmatrati. 
POLITIČKE PERSPEKTIVE

ČLANCI I STUDIJE

označen liberalom iako je njegova vanjska politika, što mu čak i Schweller priznaje (2018a), bila realistička. Trump po toj logici nužno mora biti realist, iako je on po svim kriterijima protuliberalni idealist. Primjena jedne zastarjele kategorijalne podjele glavnim je uzrokom spomenute polemike u neorealističkom krugu oko određenja Trumpove doktrine. Što se tiče Trumpovog prisvajanja epiteta realizma, ono je samo dokaz do koje je mjere ovaj teorijski binarni konstrukt ukorijenjen u intelektualnoj svijesti, zarobljenoj u dominantnom diskursu onoga što Williams naziva „tiranijom lažnog polariteta“ (2007).

\section{Protuliberalni idealizam i protuliberalna HEGEMONIJA}

U posljednjem dijelu ovog rada razmotriti ćemo pojam protuliberalni idealizam i njegove praktične učinke u kontekstu liberalnog međunarodnog poretka i američke hegemonije. Treba naglasiti da Trumpov fenomen zaista predstavlja specifični izazov za teorije međunarodnih odnosa, budući da s ovakvom doktrinom suvremena američka politika nije imala iskustva. Bilo da je riječ o realističkoj sklonosti vojnoj moći i nacionalnom interesu ili promicanju liberalnih načela i vrijednosti, jedna je stvar od 1945. bila neupitna: svijest o univerzalnom poslanju liberalnog SAD u svijetu. Trump je prvi predsjednik u novijoj povijesti koji je upravo tu neospornu vrijednost američkog društva, politike i hegemonije doveo u pitanje.

Uopće, fenomen uspona populističke desnice na Zapadu nameće potrebu promjene, odnosno uvođenja nove paradigme u teorijama međunarodnih odnosa. Tom su se pitanju posvetili Michael Williams i Jean-François Drolet u radu „Radikalni konzervativizam i globalni poredak“ (Williams and Drolet 2018). Autori ukazuju kako ideološki projekt Nove desnice, koji se šezdesetih godina dvadesetog stoljeća razvija na intelektualnim ishodištima Carla Schmitta, Oswalda Spenglera, Juliusa Evole itd., nije bio ozbiljno shvaćan, te stoga niti razmatran kao teorijska perspektiva. Njegovim se probojem na Zapadu u posljednjem desetljeću dosadašnji binarni diskurs o suprotnosti realista i liberala zamijenio novom suprotnošću između „suverenista“ i „globalista“. I dok se globalistima još uvijek označavaju one iste liberalne elite, suverenisti nisu tradicionalni konzervativci kojima se konvencionalno pripisivao realizam. Nova desnica poima državu kao jedinstvenog aktera, ali ne na materijalnom (vojnom) principu, nego na etničkom organicizmu. U stvari, konzervativna je desnica zbog svoje sklonosti kapitalizmu jednako odgovorna, kao i liberalizam, za društvenu nejednakost i ekonomske migracije. Konzervativci su prešutno odobravali politiku liberalnih elita, koje su u ime apstraktne „humanosti“ dozvolile priliv stranaca kao jeftine radne snage, izmijenivši etničku, kulturnu i duhovnu sliku nacije. 
Ipak, čini se da protuliberalni idealizam Trumpa ima svoje mjesto u kategorijalnom aparatu „klasičnog“ realizma. Mogući odgovor nudi Carrov nasljednik Martin Wight. Naime, „klasičari“ su razmatrali modalitete društvene moći unutar oprečnih kategorija zbilje i utopije (Carr), statusa quo i imperijalističkih država (Morgenthau), ili „legitimnog“ i „revolucionarnog" poretka (Kissinger). No, Wight ide korak dalje u produbljivanju i proširivanju koncepcijskih tipova realizma i idealizma. On nudi „triptih“ sastavljen od „realističke“, „racionalističke“ i „revolucionarne“ predodžbe međunarodne politike (Wight 1991, 7-15). $3^{\circ}$ Za ovu je raspravu posebno zanimljiva treća „revolucionarna“ predodžba, kao oblik utopijske, odnosno idealističke misli. Wight ju izvodi iz povijesnog iskustva tri epohalne revolucije: protestantske Reformacije, Francuske revolucije i Oktobarske revolucije. Međutim, za razliku od realističke i racionalističke tradicije, revolucionarna tradicija u sebi sadržava svoju unutarnju kontradikciju. Drugo protu-progresivno lice idealizma je kontrarevolucionarna reakcija, koja se povijesno javlja u vidu katoličke Protureformacije, Legitimizma i antikomunizma utjelovljenog u J. F. Dullesu (Bull 1976, 105).

Reakcija je ne samo srodna, već ona izravno proizlazi iz konzervativizma. Od tuda i sklonost brkanju nacionalističkih ideologija s konzervativnim realizmom. Ipak, između konzervativne i reakcionarne ideje postoji bitna razlika. Kissinger je u Obnovljenom svijetu pokazao da je konzervativna/realistička pozicija u bitnom smislu defenzivna, odnosno konzervativizam nastoji isključivo obraniti legitimnost društvenog poretka pod naletom progresivnih snaga. On određuje idealni tip konzervativca kao realističkog državnika koji protiv svoje volje biva uvučen u sukob i kojega jedino pokreće etika odgovornosti prema društvu kojemu prijeti rasap u revolucionarnom vrenju. S druge strane, idealni tip revolucionara u sukobu određen je jakom individualnom voljom za radikalnom promjenom, koju pokreće etika društvene lojalnosti prema revolucionarnoj, odnosno idealističkoj doktrini. Konzervativcu je sam pojam borbe odbojan, a osjećaj trijumfa stran; on je svjestan da poredak treba promjenu, ali putem reforme a ne revolucije. ${ }^{31}$ I upravo zbog takvog defenzivnog karaktera konzervativca, Kissinger primjećuje da „nije slučajno što u revolucionarnom sukobu konzervativnom pozicijom dominira reakcionarno - što znači kontrarevolucionarno - krilo, dakle grupa koja se bori (revolucionarnim op.a.) terminima volje i etikom lojalnosti“ (Kissinger 1976, 240). Dakle, bitno razliko-

30 Wightova tradicija „racionalizma” nema veze sa liberalnim racionalizmom o kojem je do sada bila riječ: cost-benefit analize, racionalni izbor, mikroekonomski modeli itd. Racionalizam se ovdje odnosi na zajednička pravila, norme i vrijednosti anarhičnog međunarodnog društva, te na običajne prakse i institucije međudržavnih odnosa.

31 Kissingerovo razlikovanje konzervativca i revolucionara, kao i opis sukoba pod izravnim je utjecajem Karla Mannheima i njegove Ideologije i utopije (Mannheim 2007, 249-257). 
vanje konzervativizma i reakcije ne svodi se samo na princip djelovanja nego i na konačni cilj - konzervativac s odbojnošću i nevoljko stupa u borbu kako bi sačuvao red kao takav; reakcionar s zadovoljstvom stupa u borbu kako bi restaurirao stari poredak. Za razliku od konzervativizma, reakcionarna misao ima političku viziju: to je romantičarska vizija prošlosti, koja je jednako utopijska kao i vizije budućnosti bilo „trajnog mira“ kod liberala ili „radničkog raja“ kod marksista.

Trumpova doktrina u osnovi je reakcionarna. Ona se javlja kao kontrarevolucija na revolucionarni liberalni međunarodni poredak kojeg pokreće galopirajuća globalizacija, s namjerom da revitalizira neki novi oblik vestfalskog uređenja suverenih nacija država, gotovo identičan neorealističkoj zastarjeloj hladnoratovskoj koncepciji anarhičnog sustava. Reakcija America First ponajviše se očituje u aktivističkom djelovanju Trumpovog ideologa Stevea Bannona. Turnejama po Europi on nastoji ujediniti desne suverenističke snage kako bi se nastavilo ono što on naziva „nacionalnom populističkom revolucijom" na Zapadu. ${ }^{32}$ Međutim, povijesno iskustvo pokazuje da, zbog svog utopijskog karaktera, reakcija nikada ne ostvaruje svoj konačni cilj restauracije starog poretka. Pišući o totalitarnim reakcijama na liberalizam u prvoj polovici dvadesetog stoljeća, Jose Ortega y Gasset kaže kako su kontrarevolucije osuđene na propast jer je liberalni čovjek već ostvario epohalnu pobjedu nad ne-liberalom. Reakcija predstavlja tek puku negaciju, jer umjesto da se bavi onim nakon liberalizma, ona se bavi stanjem od prije. ${ }^{33}$ Reakcija tako „nestaje u poništavajućoj praznini i ostavlja 'zastarjelo' kao pozitivan sadržaj“ (Gasset 2003, 116). Pokušaj vraćanja na staro čista je utopija koja može silom nastojati ostvariti svoj cilj i biti poražena, ali koja u većini slučajeva primorava državnika da se prilagodi strukturnim ograničenjima dane društvene zbilje. I ta činjenica dovodi do bolne spoznaje da „principijelni realizam“ u praksi izdaje sve za što se neorealisti zalažu: Trump, naime, nastavlja održavati američku hegemoniju.

Još jedan od razočaranih neorealista, Barry Posen (2018), uočio je kako je Trump tek skinuo benevolentnu masku svog prethodnika Obame, te nastavio intenzivnijim putem održavanja globalne američke hegemonije. Bez promicanja demokracije, ljudskih prava i sklapanja novih multilateralnih trgovinskih ugovora, Trumpova hegemonijska politika zanemaruje

32 Po Bannonu, početak revolucije je 2016. godina, koju obilježava Trumpova izborna pobjeda, i pobjeda breksitera na referendumu o izlasku Ujedinjenog Kraljevstva iz Europske unije (Baume and Borrelli, 2019).

33 Po tom je pitanju znamenit Trumpov ekonomski nacionalizam, koji zagovara protekcionizam kako bi se podigla zaposlenost u onim industrijama koje su odavno prevladane. Primjerice, obećanje obnove rudarske industrije u doba sve većih zahtjeva i pritisaka za uvođenje održivog razvoja i industrije, koja počiva na obnovljivim izvorima energije, predstavlja jedan čudni spoj političkog idealizma i romantičarske nostalgije. 
sve za što su se zalagali neorealisti: povlačenje (retrenchment), offshore balansiranje, selektivni angažman, održavanje veza sa tradicionalnim saveznicima na pragmatičnim osnovama, ravnoteža snaga itd. Što je, dakle, današnja „protuliberalna hegemonija“, koja se izdvaja iz dosadašnjeg benevolentnog liberalnog, odnosno prinudnog realističkog poimanja? Potrebno je naglasiti da „klasični“ realizam pretpostavlja da će međunarodni poredak biti legitiman isključivo ukoliko postoji minimalni konsenzus oko zajedničkih pravila svih aktera u sustavu. Kad je riječ o „principijelnom realizmu“ u praktičnoj primjeni, to je mješavina kontinuiteta i sporadičnog podrivanja, koje barem za sada ne ugrožava legitimnost liberalnog međunarodnog poretka.

Sukladno Jervisovoj prognozi, Trumpovo je djelovanje uglavnom u kontinuitetu održavanja dosadašnjih vanjskopolitičkih smjernica. Usprkos političkoj kampanji koja se vodi protiv Trumpove administracije oko navodnog dosluha s Rusima, Trump je u stvari pojačao sankcije Rusiji. SAD je i dalje vojno prisutan u Afganistanu, Iraku i Siriji. Što se tiče prijetnji oko razvrgavanja NATO-a zbog nepravične raspodjele tereta troškova, cilj je postignut u formalnim okvirima pregovora unutar saveza. Slična je stvar i sa Trumpovom agresivnom kampanjom protiv Sjevernoameričkog sporazuma o slobodnoj trgovini (NAFTA), koji je također pregovorima s Kanadom i Meksikom izmijenjena u jesen 2018. Konačno, Trump ne radi potpuni odmak od moralnih temelja američke vanjske politike. Nekoliko je puta naznačio svoju potporu demokraciji i ljudskim pravima kao oblik političkog pritiska na Kubu, Iran, Siriju i Venezuelu (Abrams 2019, 134-136).

S druge strane, u pojedinim slučajevima Trump unilateralnim potezima podriva liberalni međunarodni poredak, ali samo u onim sferama međunarodne politike u kojima se takvim postupcima ne mogu izazvati tektonski poremećaji u sustavu. Uglavnom su to demonstracije sile, kao što je povlačenje SAD iz Pariškog klimatskog ugovora ili objava trgovinskog rata Kini. Dugoročne posljedice takve politike najviše će doprinijeti, kako kaže Doug Stokes, „nepopravljivoj šteti prestižu SAD“, te mu posljedično suziti manevarski prostora za vanjskopolitičku strategiju u međunarodnoj politici (Stokes 2018, 150). Slučaj gdje se izravno podriva pravni legitimitet međunarodnog poretka je povlačenje SAD iz iranskog nuklearnog dogovora. Ovaj čin ne predstavlja pravo jedne države da se zbog svog interesa povuče iz takvog aranžmana, nego grubo kršenje međunarodnog prava. Dogovor je 2015, nakon desetogodišnjih diplomatskih napora, potvrđen Rezolucijom 2231 Vijeća sigurnosti UN-a, što ga čini pravno obvezujućim. 


\section{ZAKLJUČAK}

Svrha ovog rada nije ocjenjivanje dosadašnje Trumpove vanjske politike, nego dominantnog diskursa u teoriji međunarodnih odnosa, koji je upravo na fenomenu Trumpa razotkrio svoju neupotrebljivost. Teorijska podjela na realizam i liberalizam ne samo da nije od pomoći, već i navodi na krivi put, što je i nagnalo mnoge u neorealističkom krugu da na početku Trumpovog mandata njegovu vanjskopolitičku doktrinu proglase realističkom. Prevladavajući binarni diskurs u stvari je bitni odmak od prvobitne svrhe nastanka modernog realizma („klasičnog“), koji svoj identitet gradi u suprotnosti prema političkom idealizmu. Primjenom kategorijalne podjele na realizam i idealizam, pokazalo se da Trumpova doktrina, upravo zato jer ima intelektualno uporište u neorealizmu, nije realistička. Naime, neorealizam racionalizacijom koncepcija moći, države i anarhičnog sustava, koje postavlja kao univerzalne zakone međunarodne politike, posljedično postaje državo-centrična teorija fiksirana na vojnu moć i kao takva podložna ideološkom prisvajanju. Dogmatičnost prevladanih neorealističkih koncepcija iz vremena Hladnog rata Trump je jednostavno pretočio u svoj vanjskopolitički program, budući da te koncepcije odgovaraju njegovoj nacionalističkoj predodžbi svijeta. Ako je Trumpova vanjska politika usmjerena na održavanje, kako kaže Posen, protuliberalne hegemonije; onda najprikladniji pojam koji objašnjava samu doktrinu jest protuliberalni idealizam koji svoje utemeljenje nalazi u kategorijalnom aparatu još uvijek aktualnog „klasičnog“ realizma.

Ideološki uvjetovan, „principijelni realizam“ u svom reakcionarnom idealizmu zahtjeva radikalnu promjenu sustava liberalnog međunarodnog poretka. Međutim, očiti vanjskopolitički kontinuitet održavanja američke hegemonije u posljednje dvije godine Trumpovog mandata ukazuje da radikalni raskid s dosadašnjom praksom nije moguć jer - nije u skladu sa zbiljom. To i jest bio jedan od glavnih predmeta sporenja među neorealistima. Naime, neorealizam je bio i ostao hladnoratovska strateška znanost, koja se u prvi mah prepoznala u America First doktrini, iako je ta doktrina odraz okolnosti na koje neorealizam, skučen unutar gabarita ustaljenog realističko-liberalnog „, lažnog polariteta“, nema odgovora. U doba globalizacije i nametanja novih paradigmi (među ostalim, one koje nameće populistička desnica kao podjelu na politički „suverenizam“ i ,globalizam“), neorealizam je naprosto osuđen da na tržištu ideja u dogledno vrijeme ostane u sjeni. 


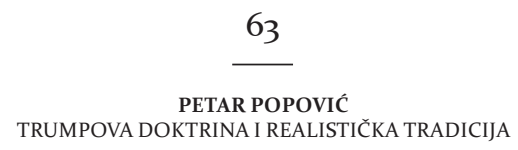

\section{LITERATURA}

Abrams, Elliot. 2019. Trump Versus the Government: Can America Get Its Story Straight? Foreign Affairs, 98 (1): 129-137.

Arendt, Hannah. 2013. Što je politika? Disput: Zagreb.

Art, Robert J. 1998/99. Geopolitics Updated: The Strategy of Selective Engagement. International Security, 23 (3): 79-113. doi: 10.2307/2539339.

Ashley, Richard. 1984. The Poverty of Neorealism. International Organization, 38 (2): 225-286. doi: 10.1017/Soo20818300026709.

Babik, Milan. 2013. Realism as a Critical Theory: The International Thought of E. H. Carr. International Studies Review, 15 (4): 491-514.

Bachevic, Andrew J. 2017. Foreign Policy 'Realists' Hit Nerve with Establishment Elite. https://www.theamericanconservative.com/articles/foreign-policy-realistshit-nerve-with-establishment-elite/ (access 22. 1. 2019).

Barkin, Samuel J. 2010. Realist Constructivism: Rethinking International Relations Theory. Cambridge: Cambridge University Press.

Baume, Maia i Silvia S. Borrelli. 2019. Welcome to Europe’s „Club“ of Populists. https://www.politico.eu/article/euroskeptics-steven-bannon-mischael-modrikamenwelcome-to-europes-first-populist-club/ (access 20. 4. 2019).

Bell, Duncan. 2009. Under an Empty Sky: Realism and Political Theory. Political Thought and International Relations, D. Bell (ed.). Oxford: Oxford University Press.

Behr, Hartmut and Amelia Heath. 2009. Misreading in IR Theory and Ideology Critique: Morgenthau, Waltz and Neo-realism. Review of International Studies, 35 (2): 327-349. doi: 10.1017/So260210509008547.

Berki, Robert N. 1981. On Political Realism. London: J. M. Dent.

Brands, Hal and Peter Feaver. 2017. Saving Realism from the So-Called Realists. https://www.commentarymagazine.com/articles/saving-realism-called-realists/ (access 22. 1. 2019).

Bull, Hedley. 1976. Martin Wight and the Theory of International Relations. International Studies, 2 (2): 101-116.

Carpenter, Ted G. 2018. Where Is Trump's Alleged Isolationism? https://www.cato. org/publications/commentary/where-trumps-alleged-isolationism (access 24. 1. 2019).

Carr, Edward H. 2001. The Twenty Years' Crisis. London: Palgrave.

Cox, Michael (ed.). 200o. E.H. Carr: A Critical Appraisal. New York: Palgrave.

Craig, Campbell. 2003. Glimmer of a New Leviathan: Total War in the Realism of Niebhur, Morgenthau and Waltz. New York: Columbia University Press. 
Drezner, Daniel. 2016. So When Will Realists Endorse Trump? https://www.washingtonpost.com/posteverything/wp/2016/o2/o1/so-when-will-realists-endorsedonald-trump/?noredirect=on\&utm_term=.27d5b1698f53 (access 31. 1. 2019).

Feher, Zoltan. 2017. Neorealist Trump: A New Grand Strategy? http://www.fletcherforum.org/home/2017/3/4/neorealist-trump-a-new-grand-strategy (acceSs 22. 1. 2019).

Gasset, Jose Ortega y. 2003. Pobuna masa. Zagreb: Golden marketing.

Gilpin, Robert. 1981. War and Change in World Politics. Cambridge: Cambridge University Press.

Grgić, Gorana. 2018. Kako je Trump za godinu dana u Bijeloj kući do temelja uništio tkivo 'stare Amerike'. https://www.tportal.hr/komentatori/clanak/kako-jetrump-za-godinu-dana-u-bijeloj-kuci-do-temelja-unistio-tkivo-stare-amerikefoto-20180119/print (pristup 22. 1. 2019).

Griffith, Martin. 1992. Realism, Idealism and International Politics: A Reinterpretation. London: Routledge.

Guilhot, Nicholas (ed.). 2011. The Invention of International Relations Theory. New York: Columbia University Press.

Gvozdev, Nikolas. 2017. The Implications of "The World is Not a Global Community". https://www.ethicsandinternationalaffairs.org/2017/implications-worldnot-global-community/ (access 13. 3. 2019).

Heldeyang, Max de. 2018. The Oxymoron Doctrine: Trump's doctrine of "principled realism" baffles the foreign policy world. https://qz.com/1401599/unga-trumpsprincipled-realism-doctrine-is-an-oxymoron/ (access 22. 1. 2019).

Ikenberry, John G. et al. (eds.). 2009. The Crisis of American Foreign Policy: Wilsonianism in the Twenty-first Century. Princeton: Princeton University Press.

Ikenberry, John G. 2012. Liberal Leviathan: The Origins, Crisis and Transformation of the American World Order. Princeton: Princeton University Press.

Jervis, Robert and F. J. Gavin (eds.). 2018. Chaos in the Liberal Order: The Trump Presidency and International Politics in the Twenty-first Century. New York: Columbia University Press.

Jervis, Robert. 2018. President Trump and IR Theory. In: R. Jervis and F. J. Gavin (eds.), Chaos in the Liberal Order: The Trump Presidency and International Politics in the Twenty-first Century. New York: Columbia University Press.

Jović, Dejan (ur.). 2013. Teorije međunarodnih odnosa: realizam. Zagreb: Politička kultura.

Jütersonke, Oliver. 2010. Morgenthau, Law and Realism. Cambridge: Cambridge University Press.

Kagan, Robert. 2002. Power and Weakness. https://web.archive.org/web/20130619163931/ http://www.newamericancentury.org/kagan-20020520.htm (access 24. 1. 2019). 


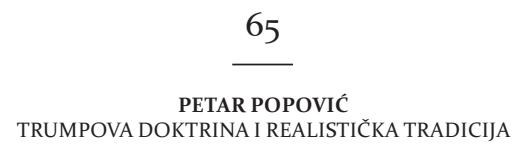

Kindelberger, Charles P. 2013. The World in Depression: 1929-1939. Berkeley: California University Press.

Kirkery, Sharon. 2018. Is Donald Trump's 'principled realism' a real doctrine? https:// nationalpost.com/news/world/is-donald-trumps-principled-realism-a-realdoctrine (access 22. 1. 2019).

Kissinger, Henry A. 1976. Obnovljeni svijet. Zagreb: Matica hrvatska.

Kissinger, Henry. 200o. Diplomacija. Zagreb: Golden marketing.

Kissinger, Henry. 2015. Svjetski poredak. Zagreb: Školska knjiga.

Larison, Daniel. 2018. No, Trump Is Not a Realist. https://www.theamericanconservative.com/larison/no-trump-is-not-a-realist/ (access 10. 2. 2019).

Latham, Robert. 1997. The Liberal Moment: Modernity, Security, and the Making of Postwar International Order. New York: Columbia University Press.

Layne, Christopher. 1997. From Preponderance to Offshore Balancing: America's Future Grand Strategy. International Security, 22 (1): 86-124. doi: 10.2307/2539331.

Lazović, Gordan Ivo. 2013. Moderna klasična realistička teorija kao reakcija na utopizam u međunarodnim odnosima. U: D. Jović (ur.). Teorije međunarodnih odnosa: realizam. Zagreb: Politička kultura.

Lebow, Richard N. 2003. The Tragic Vision of Politics. Oxford: Oxford University Press.

Mannheim, Karl. 2007. Ideologija i utopija. Zagreb: Jesenski i Turk.

Mearsheimer, John J. 1994. The False Promise of International Institutions. International Security, 19 (3): 5-49. doi: 10.2307/2539078.

Mearsheimer, John J. 2001. The Tragedy of Great Powers. New York. Norton.

Mearsheimer, John. 2014. Why the Ukraine Crisis Is the West's Fault. Foreign Affairs, 93 (5): 1-12.

Mearsheimer, John J. 2016. Donald Trump Should Embrace a Realist Foreign Policy. https://nationalinterest.org/feature/donald-trump-should-embrace-realist-foreign-policy-18502 (access 22. 1. 2019).

Molloy, Sean. 2003. Dialectis and Transformation: Exploring Exploring the International Theory of E.H. Carr. International Journal of Politics, Culture and Society, 17 (2): 279-306. doi: 10.1023/B:IJPS.0000002998.70236.ao.

Molloy, Sean. 2004. Truth, Power, Theory: Hans Moregnthau's Formulation of Realism. Diplomacy and Statecraft, 15 (1): 1-34.

Molloy, Sean. 2006. The Hidden History of Realism: A Geneaology of Power Politics. Basingstoke: Palgrave.

Morgenthau, Hans J. 1945. The Machiavellian Utopia. Ethics, 55 (2): 145-147. doi: $10.1086 / 290440$. 
POLITIČKE PERSPEKTIVE

ČLANCI I STUDIJE

Morgenthau, Hans J. 1947. Scientific Man Versus Power Politics. London: Latimer House ltd.

Morgenthu, Hans J. 1970. Truth and Power. New York/London: Praeger Publishers.

Morgenthau, Hans J. 2006. Politics Among Nations. New York: Mc Graw Hill.

Navari, Cornelia. 2017. Hans J. Morgenthau and the American Experience. London: Palgrave Mcmillan.

Neascau, Mihaela. 2009. Hans J. Morgenthau's Theory of International Relations: Disenchantment and Re-Enchantment. New York: Macmillan.

Novičić, Žaklina. 2013. Kenneth Waltz i neorealizam. U: D. Jović (ur.). Teorije međunarodnih odnosa: realizam. Zagreb: Politička kultura.

Nye, Joseph S. 2013. Transformational and Transactional Presidents. Leadership 10 (1): 118-124. doi: 10.1177/1742715013512049.

Peterson, Ulrik E. 1999. Breathing Nietzsche's Air: New Reflections on Morgnthau's Concept of Power and Human Nature. Alternatives: Global, Local, Political, 24 (1): $83-118$.

Posen, Barry. 2018. The Rise of Illiberal Hegemony: Trump's Suprising Grand Strategy. Foreign Affairs, 97 (2): 20-27.

Remarks by President Trump to the 73rd Session of the United Nations General Assembly. 25. rujna, 2018. https://www.whitehouse.gov/briefings-statements/ remarks-president-trump-73rd-session-united-nations-general-assembly-newyork-ny/ (access 22. 1. 2019).

Rösch, Felix. 2013. The Human Condition of Politics: Considering the Legacy of Hans J. Morgenthau for International Relations. Journal of International Political Theory, 9 (1): 1-21.

Scarborough, Rowan. 2017. Unlike Obama, Trump defers to generals'advice on military strategy. https://www.washingtontimes.com/news/2017/apr/9/donaldtrump-listens-to-generals-advice-on-militar/ (access 13. 3. 2019).

Scheuerman, William E. 2011. The Realist Case for Global Reform. Cambridge: Cambridge Polity Press.

Schweller, Randall. 2018a. Why Trump Now?: A Third-Image Explanation. In: R. Jervis and F. J. Gavin (eds.), Chaos in the Liberal Order: The Trump Presidency and International Politics in the Twenty-first Century. New York: Columbia University Press.

Schweller, Randall. 2018b. Three Cheers for Trump's Foreign Policy. Foreign Affairs, 97 (5): 133-143.

Stokes, Doug. 2018. Trump, American Hegemoy and the Future of the Liberal International Order. International Affairs, 94 (1): 133-150. doi: 10.1093/ia/iix238. 


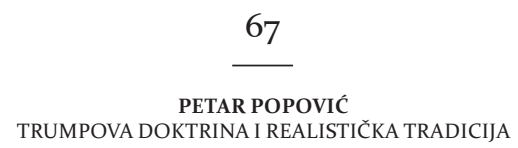

The Inaugural Address. 2017. https://www.whitehouse.gov/briefings-statements/ the-inaugural-address/ (access 31. 1. 2019).

Tjalve, Vibeke S. 2008. Realist Strategies of Republican Peace: Niebuhr, Morgenthau and the Politics of Dissent. New York: Palgrave Macmillan.

Trump, Donald J. 2016. Great Again: kako podići na noge našu onemoćalu Ameriku. Zagreb: MATE d.o.o.

Trump, Donald J. 2017. National Security Strategy of the United States of America. Washington DC: The White House.

Vukadinović, Radovan. 2005. Teorije međunarodnih odnosa. Zagreb: Politička kultura.

Waever, Ole. 1996. The Rise and Fall of the Inter-Paradigme Debate. In: S. Smith, K. Booth and M. Zalewski (eds.), International Theory: Positivism and Beyond. New York: Macmillan.

Walt, Stephen. 2009. Was Bush a (successful) realist? https://foreignpolicy. com/2009/o1/o8/was-bush-a-successful-realist/ (access 30. 1. 2019).

Walt, Stephen. 2017. What Trump Got Right About Foreign Policy. https://foreignpolicy.com/2017/o8/28/what-trump-got-right-about-foreign-policy/ (acceSS 22. 1. 2019).

Walt, Stephen. 2018. Has Trump Become a Realist? https://foreignpolicy. com/2018/04/17/has-trump-become-a-realist/ (access 22. 1. 2019).

Waltz, Kenneth N. 1990. Realist Thought and Neorealist Theory. Journal of International Affairs, 44 (1): 21-37.

Waltz, Kenneth N. 1998. Čovjek, država i rat. Zagreb: Barbat.

Waltz, Kenneth N. 20o8. Teorija međunarodne politike. Beograd: Aleksandria Press.

Wendt, Alexander. 2009. Social Theory of International Politics. Cambridge: University Press.

Wight, Martin. 1991. International Theory: The Three Traditions. Leicester: Leicester University Press.

Williams, Michael C. 2005. The Realist Tradition and the Limits of International Relations. Cambridge: Cambridge University Press.

Williams, Michael C. 2007. The Realist Tradition and the Limits of International Relations. Cambridge: Cambridge University Press.

Williams, Michael C. and Jean-François Drolet. 2018. Radical Conservatism and Global Order: International Theory and the New Right. International Theory, 10 (3): 285-313. doi: 10.1017/S175297191800012X. 
POLITIČKE PERSPEKTIVE

ČLANCI I STUDIJE

\section{SUMMARY \\ THE TRUMP DOCTRINE AND THE REALIST TRADITION}

The article's initial motive is the recent controversy among contemporary realists, who questioned the supposed realism of US president Donald Trump's foreign policy doctrine. The author argues that the polemic is a consequential outgrowth of outdated, tautological, and yet still actual binary discourse, that divides international theory and foreign policy practice on Realism and Liberalism. Referring to the established critique of Neorealism, the article argues that Neorealism does not in epistemic terms belong to the tradition of Realism, to which it is a self-proclaimed successor. On the contrary, with its notions of power, state and international system it is established in political idealism: the tradition of thought that is conventionally attributed to Liberalism, and to which "classical" Realism was fundamentally opposed. By analyzing evident congruence between principles of Neorealsim and Trump's America First doctrine, the article concludes that Trump is not a realist, but illiberal idealist. His idealistic nationalist world-view, when translated into foreign policy objectives, is in stark contrast to the professed principles of Realism. Furhtermore, the concept of illiberal idealism offers an analytical framework for further analysis of present US foreign policy in the context of its hegemonic position in the Liberal International Order.

KEY WORDS: Trump, Realism, Neorealism, Liberalism, Idealism. 